\title{
CAPTHER 42: NANO-DELIVERY SYSTEMS OF PESTICIDES ACTIVE AGENTS FOR AGRICULTURE APPLICATIONS - AN OVERVIEW
}

\author{
Carlos Rafael Silva de Oliveira' ${ }^{1}$; Jéssica Mulinari²; Francisco Wilson Reichert Júnior ${ }^{3}$; Afonso Henrique da \\ Silva Júnior ${ }^{4}$
}

\begin{abstract}
Agricultural protection agents used in soil and crops, when applied conventionally, may have their activity impaired against pests and vectors due to their volatilization, photodegradation, leaching, and other unwanted occurrences caused by weather conditions. These problems cause economic and environmental damage due to the high volume of applications necessary for the farmer to achieve the desired results. The indiscriminate use of free pesticides causes high environmental pollution because these compounds are cumulative in soil, water and vegetation, sometimes causing air contamination, which can cause health issues in local workers and the death of animals. In contrast, nanopesticides are an alternative emerging technology that allows the controlled release of active compounds, improving pest control performance and turning it more sustainable and in line with the concept of precision agriculture. The use of nano-delivery systems for pesticide agents uses nanostructures capable of altering the release kinetics of these compounds, providing the plantation with an adequate amount for pest elimination. This paper presents an overview of nanopesticides, addresses some current concepts of sustainability, reviews and analyzes the latest developments regarding these nanomaterials, and provides an update on their advantages and disadvantages.
\end{abstract}

Keywords: nanopesticides, controlled release, precision agriculture, emerging technologies, sustainable agriculture.

\section{Introduction}

Pesticides are a group of chemical compounds widely used in agriculture for pest control (Chart 1). Without them, crops would be devastated by opportunistic organisms that would eliminate or limit food production on a large scale (BAPAT et al., 2016; CAROLIN et al., 2020). Pesticide agents play a fundamental role in maintaining agricultural production, however, their indiscriminate use, in addition to being dangerous to the health of rural workers, can be highly harmful to the environment causing damage to the local biome and even to the soil (AKTAR; SENGUPTA; CHOWDHURY, 2009; CAROLIN et al., 2020).

\footnotetext{
${ }^{1}$ Textile Engineer (State University of Maringá - UEM), Master in Chemical Engineering (Federal University of Santa Catarina - UFSC), PhD student in Chemical Engineering (Federal University of Santa Catarina - UFSC), carlos.oliveira@posgrad.ufsc.br

${ }^{2}$ Environmental and Sanitary Engineer (Federal University of Fronteira Sul - UFFS), Master in Chemical Engineering (Federal University of Santa Catarina - UFSC), PhD student in Chemical Engineering (Federal University of Santa Catarina - UFSC), jessicamulinari15@gmail.com

${ }^{3}$ Agronomist (Federal University of Fronteira Sul - UFFS), Master in Environmental Science and Technology (Federal University of Fronteira Sul - UFFS), PhD student in Plant Genetic Resources (Federal University of Santa Catarina UFSC), chicowrj@gmail.com

${ }^{4}$ Agro-industrial Engineer (Federal University of Rio Grande - FURG), Master student in Chemical Engineering (Federal University of Santa Catarina - UFSC), afonso.ufsc@ gmail.com
}

[636] 
Chart 1. Classification of pesticides most used in agriculture, their target organisms, and some examples of products used in the field.

\begin{tabular}{|l|l|l|}
\hline \multicolumn{1}{|c|}{ Function } & Target organism & \multicolumn{1}{c|}{ Compound examples } \\
\hline Acaricide & Mites and ticks & Dicofol, Carbamate, DDT, organophosphates \\
\hline Algicide & Algae & Simazine, Dichlone, Benzalkonium chloride \\
\hline Fungicide & Fungi & Metalaxyl, Hexaconazole, Cymoxanil \\
\hline Herbicide & Weeds & Atrazine, Paraquat, Oxadiazon, Linuron \\
\hline Insecticide & Insects & DDT, Lindane, Thiacloprid, Clothianidin, Endosulfan \\
\hline Nematicide & Nematodes & Fenamiphos, Methyl bromide, Chlorpyrifos \\
\hline Rodenticide & Rats & $\begin{array}{l}\text { Zinc phosphide, Bromadiolone, Coumachlor, Coumatetralyl, } \\
\text { Warfarin }\end{array}$ \\
\hline Synergists & Several pests & Piperonyl butoxide \\
\hline
\end{tabular}

Source: Adapted from (SHARMA et al., 2020)

Research has shown that the number of bee colonies in the USA on agricultural land decreased from 4.4 million to 1.9 million between 1985 and 1997, due to the direct and indirect effects of pesticides, capable, for example, of weakening the immune system of bees against natural diseases and mites (HORRIGAN; LAWRENCE; WALKER, 2002). In the province of Quebec in Canada, a study on the Saint-Laurent River correlated problems in the development of local amphibious life with the presence of pesticides in the water, including body deformities, such as the growth of extra legs in places such as the abdomen and back and poorly developed limbs (OUELLET et al., 1997). Other studies have shown immune system impairment in dolphins, seals, and whales exposed to contaminated waters. In humans, direct exposure to organophosphate pesticides can lead to the appearance of lymphomas (KOUTROS et al., 2019). Organochlorine pesticides are highly carcinogenic and generate oxidative stress and mitochondrial cell malfunction (SCHMIDT et al., 2017), while carbamates lead to apoptosis (cell self-destruction) and the development of tumor cells in the central nervous system (PIEL et al., 2019). The widespread and poorly administered use of pesticides has increased the resistance of certain plant species to herbicides. Approximately 262 weed species (152 dicots and 110 monocots) are no longer responding to conventional herbicide active principles attacks worldwide. Currently, 513 unique cases in the world have been reported in 92 cultures in 70 countries according to Heap (2020).

The pesticide compounds, when applied conventionally, are released into the environment, directly reaching the soil, plants, water sources, and/or nearby vegetation, part of which are volatilized, contaminating the air, as shown in Figure 1. Until they reach the target 
(pests), pesticides find these barriers where they are retained and accumulated, thus requiring greater frequency and volume/concentration of application so that they can protect the crop at the expense of environmental poisoning (KUMAR et al., 2019).

Figure 1. Schematic illustration of possible routes of environmental contamination caused by the conventional application of pesticides.

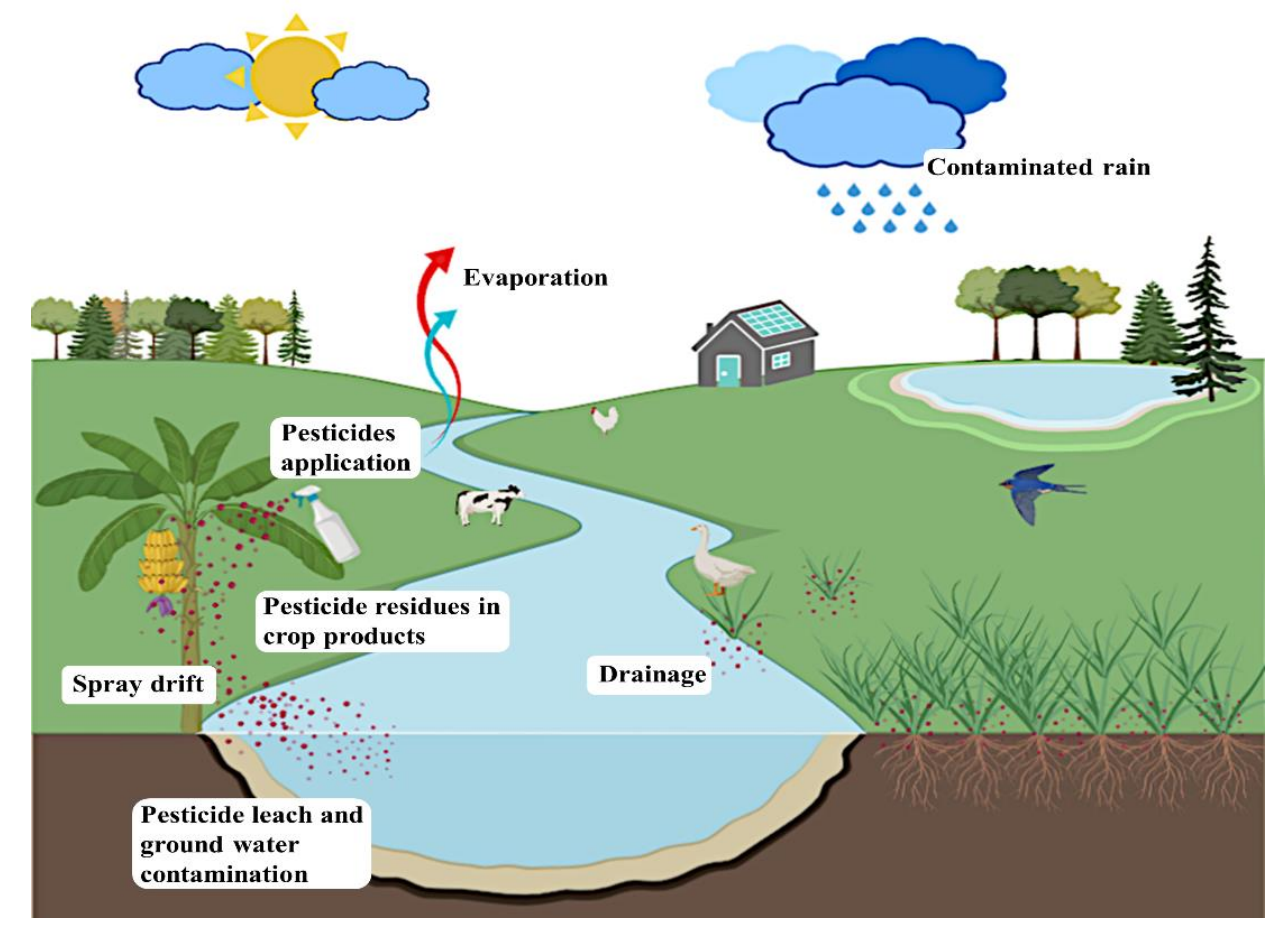

Source: Authors.

Considering that commercial pesticide formulations when applied conventionally, require large volume and frequency of applications to combat pests with unwanted environmental accumulation, the good use of pesticide agents applied to the field has become the main issue when it comes to optimizing a more safe and conscious agricultural production. It is estimated that for all pesticides applied to crops, only about $0.1 \%$ reach the target pests, leaving $99.9 \%$ of these chemical agents accumulated in the environment, raising serious environmental issues (HORRIGAN; LAWRENCE; WALKER, 2002; PIMENTEL, 2009).

In 2024 it is estimated that the global population will reach 8 billion inhabitants (ROSER; RITCHIE; ORTIZ-OSPINA, 2013). Population growth triggers an increase in the demand for food, and therefore it is safe to say that the current farming system, which is already considered unsustainable, will become unbearable if it keeps the same growth rate. The growth of the pesticide market is evident, the global pesticide market moved around $\$ 32$ billion in [638] 
2007, $\$ 56$ billion in 2012, movements of around $\$ 71$ billion are expected in 2021, and it is estimated that between 2025 and 2026 it will exceed \$100 billion (CPCM, 2016; SHARMA et al., 2017; TILMAN et al., 2001). The high discharge of pesticides into nature has bioaccumulative effects, which is why global research efforts on the use of these substances in the field are almost always to reduce the quantities of products applied without causing financial losses and reduced productivity (LECHENET et al., 2017).

Among the most promising scientific fields is nanotechnology, which has the potential to allow, at the same time, reduced use of pesticides, increased inhibition of pests in crops, increased or maintained production levels and less exposure of users to active agents during pesticides application (IRFAN et al., 2018). Since 2003, nanotechnology has been introduced in the agricultural and food industries. Initially, its applications were in food preparation and conservation, monitoring and sensing of environments and improvement of animal feed, however, it has advanced to applications in the field in the search for increased productivity through the use of nanofertilizers. More recently, it has advanced in combating pests and environmental protection with the use of nanopesticides and nanoparticles for the extraction, detection, and degradation of pesticides accumulated in the soil (BAPAT et al., 2016; HE; DENG; HWANG, 2019).

Concerns about the environment led science to find more sustainable alternatives for the application of agrochemicals in the environment, from these needs the concept of precision agriculture was originated. Precision agriculture is an innovation that follows three principles: (i) economic viability; (ii) profitability with increased production; and (iii) reduction in environmental impacts; it is recognized as a management strategy that uses information technology capable of providing accurate data for decisions associated with production in the field (ALLAHYARI; MOHAMMADZADEH; NASTIS, 2016; MONDAL; BASU, 2009; ZHANG; WANG; WANG, 2002). Nanotechnology is a tool that can improve the delivery systems of agrochemicals in cultivations in a controlled way, and also monitor the needs of the culture regarding the control of nutrients and pests through nanosensors, capable of feeding information to a system of agricultural management. Precision agriculture has spread rapidly in developed countries, research in the area began in the USA, Canada, Australia and Western Europe in the 1980s and is now worldwide (ALLAHYARI; MOHAMMADZADEH; NASTIS, 2016; MONDAL; BASU, 2009; ZHANG; WANG; WANG, 2002).

Nanostructured systems can be used as carriers of active compounds, maintaining their chemical stability against the effects of oxidation, humidity and other environmental factors, in 
addition to allowing their release into the environment in a controlled, continuous and prolonged manner (IRFAN et al., 2018). In this case, these nanometric supports doped with pesticide agents act as nano-delivery systems and can be called nanopesticides. The phenomenon of delivery of compounds in-situ occurs by mass transfer, the actives contained within the nanoparticulate support migrate by diffusion from the nucleus to the shell and, when in contact with the external environment, they can reach local pests through optimization of targeted delivery of compounds to specific target sites (ABRAHAM; PILLAI, 1996; CHEN et al., 2008; IRFAN et al., 2018; NI et al., 2011).

Generally, nano-delivery supports are prepared from biodegradable polymers such as polysaccharides (cyclodextrins, chitosan, xanthan and carboxymethylcellulose), alginic acids used to release herbicides, natural polypeptides (collagen, gelatines and amino acids), poly(lactic acid) (PLA), poly(glycolic acid) (PGA), poly(e-caprolactone) (PCL), bacterial polyesters such as polyhydroxyalkanoates (PHAs), poly( $\beta$-hydroxybutyrate) $(\mathrm{PHBs}), \operatorname{poly}(\beta-$ hydroxy-valerate) (PHV), and poly(hydroxybutyrate-co-valerate) (PHB-V), among others (DE OLIVEIRA et al., 2019; FRANCHETTI; MARCONATO, 2006; GRILLO et al., 2014; KUMAR et al., 2015; MARUYAMA et al., 2016; OLIVEIRA et al., 2018). For the reasons stated above, nanopesticides are seen as a promise of advancing agricultural technologies to make products that are less polluting, safer and more effective.

Based on the issues discussed above, the present work consists of an overview of the nano-delivery systems of active pesticide compounds used in agriculture, addressing topics related to the methods of obtaining, mechanism of action, advantages and disadvantages of these nanomaterials. Since the subject of this review is a novelty and there are few studies related to the theme in the literature, this work also sought to address current developments in the sector that may gather important information for professionals and scholars in the field.

\section{Nano-delivery systems (nanocarriers) of pesticide agents}

Conventional distribution systems are important for the application of pesticides in agriculture, these systems need to focus on improving product efficiency and managing spray diversion. A promising alternative for solving these problems is the adequate use of controlled delivery systems. The controlled delivery technique consists of releasing the pesticide compounds in adequate quantities, according to the needs of the crop, without exceeding the sufficient amounts of agrochemicals that the crop needs to overcome the target pest (TSUIJI, 2001). 
Nanotechnology has been widely considered in the adaptation and updating of conventional systems for the application of agrochemicals in the environment, searching for the global consolidation of precision agriculture (MA, 2019). Nanotechnology is the scientific and technological knowledge that uses, develops, studies, controls and/or applies materials of the order of nanometers, which structure has a diameter or at least one of its dimensions in the order of $100 \mathrm{~nm}$ or less, called nanomaterials (AUFFAN et al., 2009). Nanostructured systems can consist of nanoparticles (nanocapsules, nanospheres, nanocrystals, nanocomposites, nanotubes, nanoneedles, etc.), micro/nanoemulsions, fullerenes and biomimetic systems, which make up a wide subject to be explored in the agricultural area (GHORMADE; DESHPANDE; PAKNIKAR, 2011), as illustrated in Figure 2.

Figure 2. Some types of nanomaterials used to combat pests in agriculture.

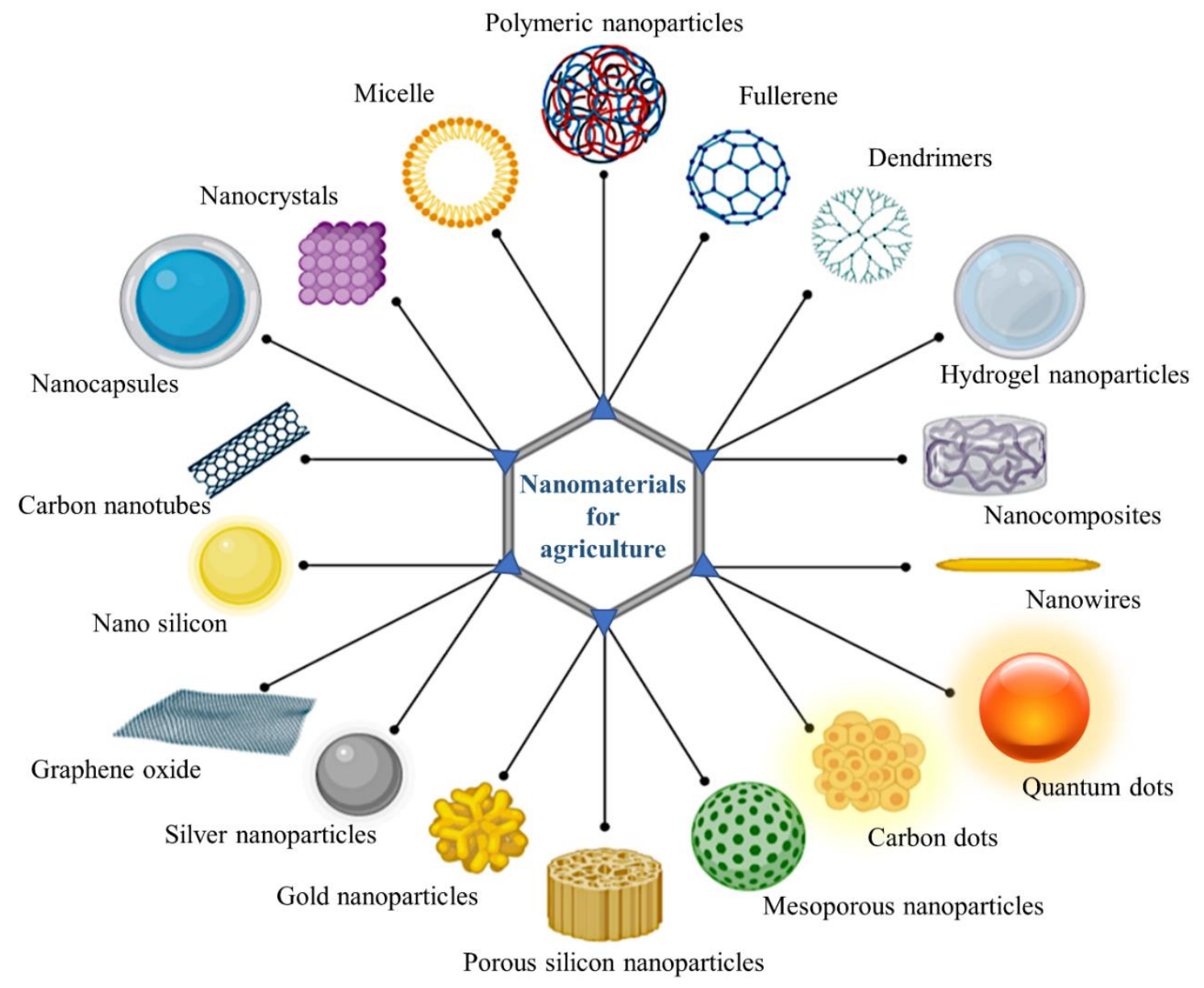

Source: Authors. 
Nanomaterials in agriculture can be used for crop protection (nanopesticides), plant nutrition (nanofertilizers), management of agricultural practices (nano[bio]sensors) and remediation (pollutant remediation nanostructured systems) (GHORMADE; DESHPANDE; PAKNIKAR, 2011). Nanostructured systems can act as transport agents for chemical compounds for cultivation, which deliver/release these substances in a slow and controlled manner, due to their small size, high surface/volume ratio, packaging of actives in a core-shell diffusion system and unique optics properties.

Several scientific researches have proven that the use of nanostructures containing active compounds behave as excellent controlled release systems for these actives. Research with particles considered to be micrometric $(10-100 \mu \mathrm{m})$, sub-micrometric $(1-10 \mu \mathrm{m})$ and nanometric $(<1 \mu \mathrm{m})$ used as support for controlled delivery of agrochemicals reported that the nanometric ones have advantages over the others because they have greater surface area per unit volume, easy fixation and accelerated mass transfer (GHORMADE; DESHPANDE; PAKNIKAR, 2011). Several materials can be used as nanoparticles or compose nanostructured systems for applications in the field such as quantum dots, metal oxides, biopolymers (synthetic or natural), clay minerals, emulsions, lipids, peptides, dendrimers, among others (PUOCI; et al., 2008).

\section{Mechanisms of action and release of active compounds}

For a chemical product of crop protection to be successful, it must remain active in the environment regardless of weather (cold, rain, heat, sun, etc.) as well as reach and penetrate the target organism (insects, phytopathogens, etc.). It must also resist the defense mechanisms of the pest, must be benign to the soil and the cultivation, inactive in non-target organisms, have profitable manufacture and offer good economic return (SMITH; EVANS; EL-HITI, 2008).

In addition to transport vehicles, nanocarriers in many cases act as a protective container for active components against adverse external conditions (high temperature, radiation, high humidity, oxidation, among others), increasing their physical and chemical stability. The nanodelivery systems must follow an intelligent principle of controlled release of the chemical compound at the destination site in a manner appropriate to the specific needs (COOPER, 2010; FLORES-CÉSPEDES et al., 2015; MARUYAMA et al., 2016). The main functions of the nanocarriers, in this case, are (i) to retain/protect the active compounds without release or loss before they reach the target; (ii) to improve the dissolution of the compounds when they reach the target, for example, improving the penetration in the plant tissues of the weeds; and (iii) to 
change/control the active release functions in neighboring environments. These functions depend directly on the size, shape, and material from which the nanocarrier is made (COOPER, 2010; FLORES-CÉSPEDES et al., 2015; MARUYAMA et al., 2016).

Various materials can be applied in the preparation of nanopesticides: from polymers (natural and synthetic), waxes/lipids, proteins/peptides to oxides and clay minerals (IRFAN et al., 2018; LI et al., 2007). The geometry of the nanostructures is related to the surface area per unit of volume, and therefore the shape of the nanocarrier is extremely important in defining the release and protection profile of the actives. These nanomaterials can be designed for (i) slow-release; (ii) quick release; (iii) selective release; (iv) moisture release; (v) release by heat; (vi) release by $\mathrm{pH}$; (vii) release by ultrasound; (viii) magnetic release; and (ix) release by DNA profile (LI et al., 2007).

Polymeric nanocapsules are the supports most commonly used as nanocarriers, mainly biodegradable polymers such as chitosan, alginate, gelatin, collagen, carboxymethylcellulose, polyethylene glycol (PEG), among others (KUMAR et al., 2018; RANI et al., 2017). Nanocapsules consist of a shell or membrane structure that surrounds the active compound and retains it in its core. Numerous factors can interfere with the delivery mechanisms of the nanocapsules, in general, the release occurs through the diffusion of the active compound contained in the nucleus through the polymeric membrane until it reaches the shell (surface), where it is finally exposed to different stimuli from the external environment (IRFAN et al., 2018). Some of the important factors that can significantly affect the controlled release mechanism of these nanostructures include the mechanical properties and level of biodegradability of the coating material, the thickness of the coating, the density of the actives, the physiology and water content of the soil (IRFAN et al., 2018). The complexity of the phenomena can include the transport of water through the coating, the condensation of water in the nucleus of the nanocapsule, the development of osmotic pressure, the dilution of the active compounds, the swelling of the granule, the modification of the micropores, among others (IRFAN et al., 2018).

In addition to the general mechanisms for releasing active compounds from their matrices, different strategies for applying these nanostructures can also be studied to improve the effectiveness of pest control in situ. Sharma et al. (2017) synthesized copper selenide nanoparticles decorated in graphene nanoparticles doped with chlorpyrifos (insecticide) for foliar application in vegetable culture. The authors developed a hydrophobic material with adhesive properties, which when applied to the leaves do not leach easily with rain. When the 
nanomaterial applied to the leaves comes in contact with the body of the larvae of Pieris rapae (worm), the nanopesticide adhere to the insect and slowly poison it until its death. The authors report that graphene acts as an adhesion support, while the pesticide agent acts by poisoning the animal organism. Copper selenide nanoparticles act in three ways: poisoning when ingested by the insect, assisting the daytime release of the insecticidal compound due to its photothermal activity, and helping in the degradation of the pesticide that remains in the leaves left in the field after the time of cultivation. The authors reported that the nano-support developed showed resistance to bad weather, controlled release, and increased larval mortality by more than $35 \%$.

The release of agrochemicals from a colloidal nanoparticle system is similar to that of other active compounds released from nanostructures. The delivery of pesticide agents incorporated and/or adsorbed on nanocarriers can occur through different mechanisms, among which it is possible to mention the release by (i) diffusion; (ii) dissolution; (iii) erosion; (iv) fragmentation; and (v) swelling, which may occur alone or together (BAKER, 1987; LIECHTY et al., 2010; PEPPAS et al., 2000), as shown in Figure 3.

Figure 3. Some of the most common mechanisms for releasing active compounds from nanocarriers.

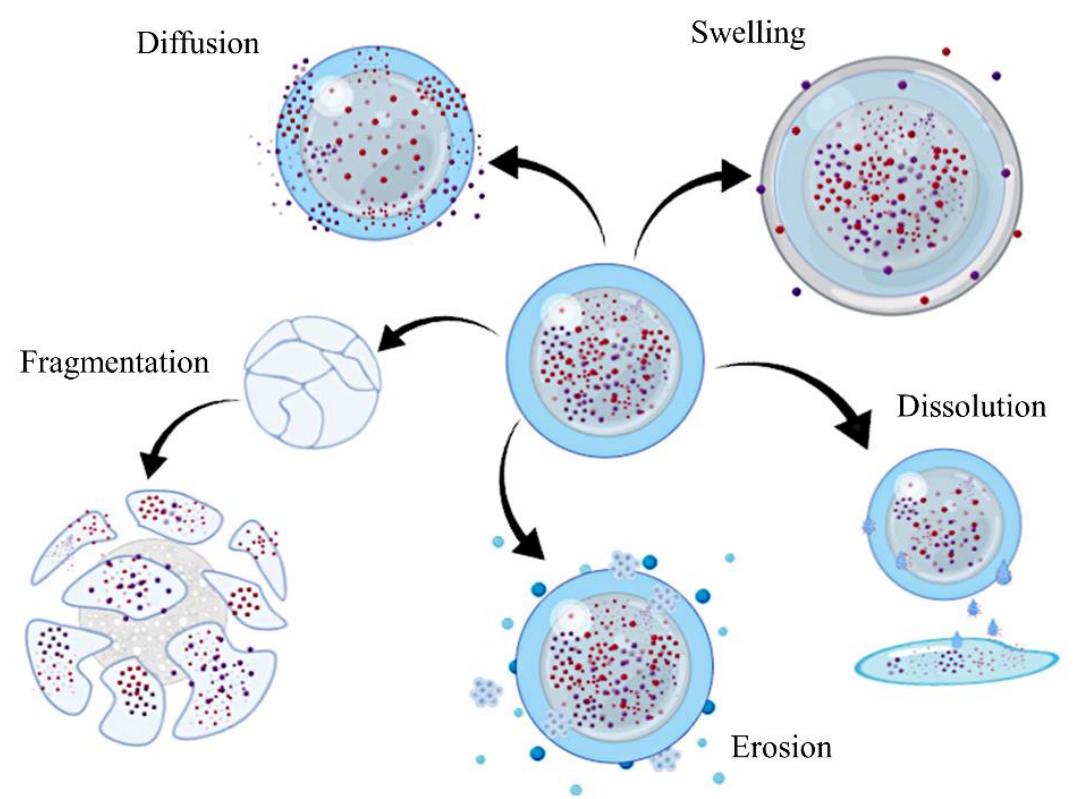

Source: Authors.

\section{Diffusion}

In this case, the release of the active compound (solute) occurs by molecular diffusion, through the matrix (support). The particle matrix can remain intact or with few changes [644] 
throughout the diffusion process, or it can undergo considerable changes due to its dissolution/fragmentation, for example (MCCLEMENTS, 2017). In this mechanism, the release rate of the actives depends on several factors, such as the chemical properties of the solute (polarity, molecular weight, volatility, among others), physical-chemical properties of the matrix (density, rheology, polarity, physical state, cross-linking state, and others), the physical characteristics of the particle (size, shape, crystallinity, etc.) and the gradient of contraction of the solute through the matrix in the core-shell direction (BAKER, 1987; LIECHTY et al., 2010; PEPPAS et al., 2000).

\section{Dissolution}

This active delivery/release mechanism occurs when the nanostructure comes in contact with specific environmental solutions or conditions capable of causing its dissolution (BAKER, 1987; MCCLEMENTS, 2017). In cases where the nanocarrier is the active compound itself, its release occurs in the medium as it dissolves. When the matrix is soluble, the active agent contained within it is released as the carrier matrix dissolves. In these cases, the release rate of the actives depends on the particle composition and the magnitude, the type and the duration of the environmental conditions that cause the dissolution (temperature, $\mathrm{pH}$, ionic strength, humidity, etc.) (BAKER, 1987; LIECHTY et al., 2010; PEPPAS et al., 2000).

\section{Erosion}

In this case, the pesticidal compounds are released as the carrier matrix erodes due to specific environmental conditions. Erosion is a process of molecular chemical degradation of the matrix, which can occur in mass (in the whole particle) or only on the surface (outside the particle). Erosion is a phenomenon that can occur due to chemical (e.g. $\mathrm{pH}$ or the presence of strong acids/bases), physical (e.g. high/low temperature), and/or biological factors (e.g. enzyme action) (MCCLEMENTS, 2017). In this type of mechanism, the release rate depends on the speed and the erosion profile. For this mechanism, as well as for the others, other phenomena can occur simultaneously, for example, secondary processes of fragmentation and dissolution can interfere in the main erosion process, in which case the release rate will be influenced by these additional variables (BAKER, 1987).

\section{Fragmentation}


In this case, the release of pesticide actives is dependent on the fragmentation rate of the carrier matrix. Fragmentation is a process in which the nanostructure acquires fractures caused by physical disturbances of climatic, mechanical, chemical, physical, or enzymatic origin (BAKER, 1987). Due to the stresses suffered, the cracked nanostructure starts to fragment, pieces are loosened and released continuously in the medium in smaller and smaller sizes until complete degradation (BAKER, 1987; MCCLEMENTS, 2017).

\section{Swelling}

This mechanism includes the system for releasing actives that occur from the swelling of the matrix, caused by solvents and environmental conditions. In this case, the particles find favorable conditions for their swelling in the environment in which they are exposed. The swelling of the particles occurs due to an increase in the internal pore size. When the pore size reaches a value similar to the molecular size of the active compound, it becomes an escape route for this compound to the external environment. In this mechanism, the pesticide release rate will depend mainly on the swelling rate and the diffusion time through the matrix (BAKER, 1987; LIECHTY et al., 2010; PEPPAS et al., 2000).

\section{Developments, applications and results: some current approaches}

This section presents an update on new developments in the field of nano-based agricultural protection, in which some works were briefly presented. Table 2 shows some relevant research carried out in the last 5 years, in which the authors developed, applied, and evaluated the use of nano-delivery systems (nanocarriers) of pesticide agents for agriculture.

Maghsoudi and Jalali (2017) investigated the performance of graphene oxide nanosheets as photoprotectors of Bacillus thuringiensis against solar UV radiation. $B$. thuringiensis is a gram-positive spore-forming bacterium widely used in crops as a biopesticide since the 1940s. Although ecologically correct, the effectiveness of this bacterium in combating pests is sometimes impaired due to its low stability to environmental factors, such as natural UV radiation that is capable of causing its death. The team tested the larval resistance for $96 \mathrm{~h}$ under radiation in the isolated presence of graphene oxide, olive oil, olive oil mixed with graphene oxide, and free spores. The authors observed that larval mortality was $56 \%, 47 \%$, $69 \%$, and $40 \%$, respectively, indicating that graphene oxide and olive oil achieved better results 
when applied together. The authors also mentioned that the results found exceed some results in the literature that use other photoprotection agents, such as molasses.

Suriyaprabha et al. (2014) used silica nanoparticles $(20-40 \mathrm{~nm})$ to treat Fusarium oxysporum and Aspergillus niger, two species of fungi that attack vegetables and legumes. The authors tested the application of nanosilica for the treatment of corn, and observed that a greater expression of phenolic compounds $(2056 \mathrm{mg} / \mathrm{mL})$ and less expression of stress-responsive enzymes $(743 \mathrm{mg} / \mathrm{mL})$ were found in leaf extracts from treated plants. The authors reported that the treated corn expressed greater resistance to Aspergillus niger, and that the same treatment carried out with silica in bulk did not present significant results in comparison to the results with nanosilica in terms of disease index and total phenol, peroxidases, polyphenol oxidase, and phenylalanine ammonia-lyase content. Therefore, they concluded that the silica nanoparticles had excellent antifungal properties and therefore can be considered as an alternative to combat phytopathogens.

Kumar et al. (2015) developed nanocapsules containing acetamiprid, a pesticidal agent. The nanocapsules were prepared by complexing alginate and chitosan polyelectrolytes and tested for controlled in vitro release under three different $\mathrm{pH}$ conditions. To obtain the nanocapsules, the team prepared two independent aqueous solutions of chitosan in acetic acid and alginate, with a corrected $\mathrm{pH}$ of 4.6 and 4.9 respectively. The pesticidal compound was ultrasonicated in the alginate solution and then a solution of calcium chloride was slowly added to the mixture. Under constant agitation, the chitosan solution was added slowly to the previous mixture. The recovery of the nanocapsules occurred after washing and centrifugation $(14,000$ $\mathrm{rpm})$. The results revealed that the maximum release occurred at $\mathrm{pH} 10$, and the lowest release at $\mathrm{pH} 4$, and that the nanoparticles showed a controlled release of the insecticide for up to $36 \mathrm{~h}$.

Maruyama et al. (2016) studied the nanoencapsulation of the herbicides imazapic and imazapyr in nanoparticles of alginate-chitosan and chitosan-tripolyphosphate, obtained by ionotropic gelation. For the preparation, they used a solution of sodium alginate in which the herbicidal compounds were added. After preparation, a solution of calcium chloride was added dropwise to obtain a pre-gel after $30 \mathrm{~min}$ of stirring. Then a solution of chitosan in acetic acid was added to the mixture and kept for $12 \mathrm{~h}$ under vigorous stirring to obtain the nanoparticles. For the preparation of chitosan-tripolyphosphate nanoparticles, the team prepared a solution of chitosan in acetic acid and later added the herbicidal compounds. Then a tripolyphosphate solution at $\mathrm{pH} 4.5$ at $8{ }^{\circ} \mathrm{C}$ was added, and the mixture was kept under stirring for $12 \mathrm{~h}$. The nanoparticles had an average size of $400 \mathrm{~nm}$ and showed excellent stability stored at room 
temperature for 30 days. In the end, they found that the nanoencapsulated herbicides showed greater efficiency and less genotoxicity when compared to the results of free compounds.

Yang et al. (2009) developed nanoparticles from polyethylene glycol (PEG) loaded with garlic essential oil to assess insecticidal activity against adult Tribolium castaneum (brown beetle). The nanoparticles prepared by the fusion dispersion method had a rounded shape and good size distribution with an average diameter of $240 \mathrm{~nm}$. The authors tested the application of free and encapsulated oil and observed that the efficacy against $T$. castaneum remained over $80 \%$ even after five months when the nanoparticles were applied, while the application of free garlic oil reached only $11 \%$ of efficacy using the same concentration. Finally, they attributed the success of the application to the controlled release of the active garlic compound into the environment.

Campos et al. (2018a) used cyclodextrins to functionalize chitosan using a nano complexation method. The obtained mixture was used to encapsulate carvacrol and linalool, which are two phenolic monoterpenes extracted from herbs with insecticidal and repellent properties. The nano complexation of the biopolymers allowed an increase in the product's life due to the greater control of release and volatilization of the encapsulated essential compounds. The same group used zein, a protein obtained from the endosperm of corn kernels to encapsulate citronella, eugenol, geraniol oils, and cinnamaldehyde, which are natural compounds used in insect control (DE OLIVEIRA et al., 2019).

Kumar, Kumar, and Dilbaghi (2017) prepared chitosan-pectin nanoparticles loaded with carbendazim (active pesticide) to combat Fusarium oxysporum and Aspergillus parasiticus. Chitosan-pectin nanoparticles were obtained by ionic interaction method. The authors separately made the dilution of chitosan in acetic acid and pectin in distilled water, under adequate sonification. Aqueous solutions of carbendazim dissolved in acetic acid, and sodium dioctyl sulfosuccinate (surfactant) were prepared. During 3 hours under vigorous stirring, the authors slowly dripped the pectin, carbendazim, and sulfosuccinate solutions simultaneously into the chitosan solution. After the reaction, the medium containing the nanoparticles was centrifuged for 1 hour at 10,000 rpm, the decanted was washed several times and lyophilized with mannitol (cryoprotectant). The authors obtained nanoparticles between 70 and $90 \mathrm{~nm}$ that showed $100 \%$ inhibition of fungi at concentrations of 0.5 and $1 \mathrm{ppm}$, while for pure carbendazim they observed 80 and $97 \%$ for the same concentrations, respectively. Based on the many tests carried out, the authors concluded that nano-formulated carbendazim is more 
effective and safer for the germination and root growth of Cucumis sativa (cucumber) seeds than the compound applied directly.

Shyla, Natarajan, and Nakkeeran (2014) chemically synthesized nanoparticles of titanium dioxide $\left(\mathrm{TiO}_{2}\right)$, zinc oxide $(\mathrm{ZnO})$ and silver $(\mathrm{Ag})$, and tested their effectiveness in combating Macrophomina phaseolina, a soil fungus that causes the root and stem rot of many plants, until their death. The synthesized nanoparticles showed an excellent average size distribution of $35-45,20-80,85-100 \mathrm{~nm}$, for $\mathrm{ZnO}, \mathrm{Ag}$, and $\mathrm{TiO}_{2}$ respectively. The best result was obtained by the application of silver nanoparticles and in lower concentrations than those used for the others. Sidhu, Barmota, and Bala (2017) produced copper sulfide nanoaquaformulations by the sonochemical method, followed by microwave irradiations in the presence of capping agents (polyvinylpyrrolidone, 4-aminobutyric acid or tri-sodium citrate). The authors tested the colloidal system in vitro for antifungal action in rice seeds. Studies have shown multiple efficacy against Alternaria alternata, Drechslera oryzae, and Curvularia luneta. The team also observed a significant reduction in seed rot and pest content in the seedlings, in addition to favorable effects on seed germination and plant growth.

Oliveira et al. (2015) prepared poly(e-caprolactone) (PCL) nanocapsules with an average diameter of $241 \mathrm{~nm}$ containing atrazine as an active pesticide. The authors tested the post-emergence herbicidal activity of nanocapsules for target plant species. The herbicidal activity was noticed even after $72 \mathrm{~h}$ in Brassica juncea; the team also observed lower toxicity of encapsulated atrazine compared to the application of the free herbicide. Guo et al. (2015) developed silica microcapsules cross-linked with carboxymethylcellulose and epichlorohydrin, containing emactite benzoate as an insecticidal agent. The authors obtained capsules with an average size of 1 and $3 \mu \mathrm{m}$ using the emulsion polymerization method, and their insecticidal action was tested against Myzus persicae. The authors observed excellent cellulase-responsive property, high efficacy against $M$. persicae, and less genotoxicity with Allium cepa. 
Chart 2. Some relevant researches on the development, application and evaluation of nanocarrier systems of pesticide agents, from the last 5 years.

\begin{tabular}{|c|c|c|c|c|c|}
\hline $\begin{array}{l}\text { Nanocarrier / (average } \\
\text { size) }\end{array}$ & Pesticide Agent & Preparation method & Application & Results & Reference \\
\hline $\begin{array}{l}\text { Nanoparticles of } \\
\text { mesoporous silica and } \\
\text { trimethylammonium / } \\
(423 \mathrm{~nm})\end{array}$ & $\begin{array}{l}2,4- \\
\text { dichlorophenoxy } \\
\text { acetic acid }\end{array}$ & $\begin{array}{l}\text { Sol-gel and } \\
\text { nanosilica graft post }\end{array}$ & $\begin{array}{l}\text { Herbicidal action } \\
\text { against dicot plants }\end{array}$ & $\begin{array}{l}\text { Electrostatic interactions were the driving } \\
\text { forces that induced the loading of } \\
\text { pesticides, and regulated the compound } \\
\text { release by decreasing leaching in the soil. }\end{array}$ & $\begin{array}{l}\text { (CAO et al., } \\
2018)\end{array}$ \\
\hline $\begin{array}{l}\text { Silica gel microparticles } \\
\text { loaded with } \mathrm{ZnO} \text { and } \\
\text { copper nanoparticles / } \\
(600 \mathrm{~nm}-1.1 \mu \mathrm{m})\end{array}$ & --- & $\begin{array}{l}\text { Chemical reaction in } \\
\text { aqueous dispersion }\end{array}$ & $\begin{array}{l}\text { Antimicrobial action } \\
\text { against Xanthomonas } \\
\text { alfafae, Pseudomonas } \\
\text { syringae, and } \\
\text { Clavibacter } \\
\text { michiganensis }\end{array}$ & $\begin{array}{l}\text { Excellent antimicrobial activity and high } \\
\text { effectiveness in the control of citrus canker } \\
\text { in Ruby grapefruit. }\end{array}$ & $\begin{array}{l}\text { (YOUNG et al., } \\
\text { 2018) }\end{array}$ \\
\hline $\begin{array}{l}\text { 2-nitrobenzyl- } \\
\text { carboxymethyl-chitosan } \\
\text { succinate micelles / } \\
(140 \mathrm{~nm})\end{array}$ & Diuron & $\begin{array}{l}\text { Graft of side chains } \\
\text { and method of } \\
\text { conjugation }\end{array}$ & $\begin{array}{l}\text { Photo-controlled } \\
\text { pesticide release }\end{array}$ & $\begin{array}{l}\text { High rate of photo-controlled release } \\
(96.8 \%) \text { for up to } 8 \mathrm{~h}(\text { at } \mathrm{pH} 7) \text { under solar } \\
\text { radiation stimulus. }\end{array}$ & (YE et al., 2015) \\
\hline $\begin{array}{l}\text { Hollow } \mathrm{TiO}_{2} \\
\text { nanoparticles doped } \\
\text { with } \mathrm{Ag} /(<50 \mathrm{~nm})\end{array}$ & --- & $\begin{array}{l}\text { Chemical reaction in } \\
\text { alcoholic dispersion }\end{array}$ & $\begin{array}{l}\text { Fungicidal action } \\
\text { against Fusarium } \\
\text { solani and Venturia } \\
\text { inaequalis }\end{array}$ & $\begin{array}{l}\text { Excellent fungicidal activity under natural } \\
\text { lighting (visible light). }\end{array}$ & $\begin{array}{l}\text { (BOXI; } \\
\text { MUKHERJEE; } \\
\text { PARIA, 2016) }\end{array}$ \\
\hline $\begin{array}{l}\text { Chitosan and gum } \\
\text { arabic nanoparticles / } \\
(\sim 226 \mathrm{~nm})\end{array}$ & $\begin{array}{l}\text { Carvacrol e } \\
\text { Linalool }\end{array}$ & Ionic gelation & $\begin{array}{l}\text { Insecticidal action } \\
\text { against Helicoverpa } \\
\text { armigera } \text { and } \\
\text { Tetranychus urticae }\end{array}$ & $\begin{array}{l}\text { Excellent insecticidal action and increased } \\
\text { mortality rate. The compounds applied } \\
\text { together showed better results than when } \\
\text { applied alone. }\end{array}$ & $\begin{array}{l}\text { (CAMPOS et } \\
\text { al., 2018b) }\end{array}$ \\
\hline $\begin{array}{l}\text { Zein nanoparticles / } \\
(278 \pm 61.5 \mathrm{~nm})\end{array}$ & Neem oil & $\begin{array}{l}\text { Anti-solvent } \\
\text { precipitation }\end{array}$ & $\begin{array}{l}\text { Investigation of toxicity } \\
\text { to non-target organisms }\end{array}$ & $\begin{array}{l}\text { The nanocapsules showed less genotoxicity } \\
\text { to Allium cepa than free Neem oil, there } \\
\text { was no change in soil biota, and safe } \\
\text { application for Caenorhabditis elegans. }\end{array}$ & $\begin{array}{l}\text { (PASCOLI et } \\
\text { al., 2019) }\end{array}$ \\
\hline $\begin{array}{l}\text { Microspheres of vinyl } \\
\text { polyacetate (PVA) / } \\
(320 \mathrm{~nm})\end{array}$ & $\begin{array}{l}\text { Emamectin- } \\
\text { benzoate (EMB) }\end{array}$ & $\begin{array}{l}\text { Microemulsion } \\
\text { polymerization }\end{array}$ & $\begin{array}{l}\text { Slow and controlled } \\
\text { release pesticide action }\end{array}$ & $\begin{array}{l}\text { Excellent photoprotective capacity of active } \\
\text { agents, good stability of microspheres } \\
\text { under natural conditions, and gradual EMB } \\
\text { release over } 200 \mathrm{~h} \text {. }\end{array}$ & $\begin{array}{l}\text { (WANG et al., } \\
\text { 2017) }\end{array}$ \\
\hline
\end{tabular}

Source: Authors 


\section{Disadvantages in the use of nanopesticides: a critical view}

Throughout the review on the use of nano-delivery systems in agriculture, it became clear that nanotechnology is undoubtedly an ally in the development of solutions for cultivation. Its gains, advantages, and benefits have been exhaustively exemplified, but it has not been mentioned what are the real challenges encountered for the wide use of these nanomaterials, the risks offered, and the disadvantages they can cause. It is clear that for many specific applications, normally under controlled conditions, the results of the use of nanocarriers have shown an increase in application effectiveness and levels of preservation of the environment never seen before (DANG et al., 2010; KIM et al., 2018). The results of serious and reputable scientific researches have indicated that the use of pesticide nano-delivery systems in the field is a viable, promising and more sustainable alternative when compared to the conventional pesticide application system, which occurs due to the indiscriminate spillage of free agrochemicals in crops and soil, most often by direct spraying (DANG et al., 2010; KIM et al., 2018). Virtually all studies are concerned with only developing some technology that shows signs of positive and sustainable results, but there is no concern with studying the financial viability and economic consequences of its use (DIMKPA; BINDRABAN, 2018).

In recent decades, a large number of patents have been issued for works related to the development and application of nanomaterials containing pesticide agents for agriculture. However, the commercialization of these materials is extremely limited due to numerous challenges and knowledge gaps around their use (KIM et al., 2018). Some of the challenges for advancing the use of nanotechnology include low investments in teaching and research/development infrastructure, the high cost of producing nanomaterials, low agricultural financial return, the resistance of the agricultural sector in the implementation of nanomaterials in the field, among other limitations that delay progression (HUANG et al., 2015; PARISI; VIGANI; RODRÍGUEZ-CEREZO, 2015). Several technical restrictions in the scope of industrial production of nanopesticides limit the advance in the use of these materials, for example, the high energy demand of the processes involved (DIMKPA; BINDRABAN, 2018). Due to their size, nanoformulations tend to form clusters, or even dissolve the matrix, which alters their surface chemical properties. The aggregation of nanoparticles transforms them into non-nanological formulations, which is contrary to their main creation objective (DIMKPA; BINDRABAN, 2018). Other obstacles that the advancement of the use of these nanomaterials face are the unknown risks that the absorption and accumulation of nanomaterials in foods can present. The presence of more resistant agrochemicals in food can contaminate the food chain 
creating imminent health hazards for humans and animals, and even for the environment (MANCHIKANTI, 2019; PENG et al., 2017; VILCHEZ-ARUANI et al., 2020).

\section{Final Considerations}

Nanopesticides are a class of materials used to combat and control pests harmful to food and crops. These materials are based on nanometric systems for the actuation and/or delivery of active compounds in the field. Thus, nano-delivery systems for pesticides have been widely studied in an attempt to find effective solutions to current problems of environmental pollution, low efficiency of conventional application systems, and less toxicity to users and food. Numerous advantages have been reported in the literature in the use of these nanomaterials, and a very promising and more sustainable future can be expected from these nanostructures compared to traditional agriculture. However, some issues that slow the advance of the use of nanopesticides in the agricultural sector have limited the evolution of industrial production and the consolidation of these materials in the market. Another worrying factor is that little is known about the possible risks that these nanoformulations can cause. Therefore, further studies and more consolidated concepts are needed regarding health safety in the use of nanomaterials, their mechanisms of action, bioaccumulation behavior, cost of processing, the economic viability of production, marketing logistics, the stability of nanoformulation stock, ways of application in the field, and financial return to the producer. For these reasons, nanopesticides are still considered an emerging, revolutionary technology, in wide expansion and very promising if treated with awareness.

\section{References}

ABRAHAM, J.; PILLAI, V. N. R. Membrane-encapsulated controlled-release urea fertilizers based on acrylamide copolymers. Journal of Applied Polymer Science, v. 60, n. 13, p. 2347 2351, 1996.

AKTAR, W.; SENGUPTA, D.; CHOWDHURY, A. Impact of pesticides use in agriculture: Their benefits and hazards. Interdisciplinary Toxicology, v. 2, n. 1, p. 1-12, 2009.

ALLAHYARI, M. S.; MOHAMMADZADEH, M.; NASTIS, S. A. Agricultural experts' attitude towards precision agriculture: Evidence from Guilan Agricultural Organization, Northern Iran. Information Processing in Agriculture, v. 3, n. 3, p. 183-189, 2016.

AUFFAN, M. et al. Towards a definition of inorganic nanoparticles from an environmental, health and safety perspective. Nature Nanotechnology, v. 4, n. 10, p. 634-641, 2009.

BAKER, R. W. Controlled Release of Biologically Active Agents. 4. ed. New York: John Wiley \& Sons, 1987. 
BAPAT, G. et al. Silica nanoparticle based techniques for extraction, detection, and degradation of pesticides. Advances in Colloid and Interface Science, v. 237, p. 1-14, 2016.

BOXI, S. S.; MUKHERJEE, K.; PARIA, S. Ag doped hollow TiO2 nanoparticles as an effective green fungicide against Fusarium solani and Venturia inaequalis phytopathogens. Nanotechnology, v. 27, n. 8, 2016.

CAMPOS, E. V. R. et al. Chitosan nanoparticles functionalized with $\beta$-cyclodextrin: A promising carrier for botanical pesticides. Scientific Reports, v. 8, n. 1, p. 1-15, 2018a.

CAMPOS, E. V. R. et al. Carvacrol and linalool co-loaded in $\beta$-cyclodextrin-grafted chitosan nanoparticles as sustainable biopesticide aiming pest control. Scientific Reports, v. 8, n. 1, p. $1-14,2018 b$.

CAO, L. et al. Positive-Charge Functionalized Mesoporous Silica Nanoparticles as Nanocarriers for Controlled 2,4-Dichlorophenoxy Acetic Acid Sodium Salt Release. Journal of Agricultural and Food Chemistry, v. 66, n. 26, p. 6594-6603, 2018.

CAROLIN, F. et al. Recent advancements in rapid analysis of pesticides using nano biosensors : A present and future perspective. Journal of Cleaner Production, v. 269, p. 122356, 2020.

CHEN, L. et al. Controlled release of urea encapsulated by starch-g-poly(l-lactide). Carbohydrate Polymers, v. 72, n. 2, p. 342-348, 2008.

COOPER, E. R. Nanoparticles: A personal experience for formulating poorly water soluble drugs. Journal of Controlled Release, v. 141, n. 3, p. 300-302, 2010.

CPCM. Crop Protection Chemicals Market by Type (Herbicides, Insecticides, and Fungicides), Origin (Synthetic, and Biopesticides), Crop Type (Cereals \& Oilseeds, Fruits \& Vegetables), Mode of Application, Form, and by Region - Global Forecasts to 2021Market Research Report. [s.l: s.n.]. Disponível em: <https://www.marketsandmarkets.com/Market-Reports/crop-protection-380.html>.

DANG, Y. et al. Trends in worldwide nanotechnology patent applications: 1991 to 2008. Journal of Nanoparticle Research, v. 12, n. 3, p. 687-706, 2010.

DE OLIVEIRA, J. L. et al. Association of zein nanoparticles with botanical compounds for effective pest control systems. Pest Management Science, v. 75, n. 7, p. 1855-1865, 2019.

DIMKPA, C. O.; BINDRABAN, P. S. Nanofertilizers: New Products for the Industry? Journal of Agricultural and Food Chemistry, v. 66, n. 26, p. 6462-6473, 2018.

FLORES-CÉSPEDES, F. et al. Preparation and Characterization of Azadirachtin AlginateBiosorbent Based Formulations: Water Release Kinetics and Photodegradation Study. Journal of Agricultural and Food Chemistry, v. 63, n. 38, p. 8391-8398, 2015.

FRANCHETTI, S. M. M.; MARCONATO, J. C. Polímeros biodegradáveis - Uma solução parcial para diminuir a quantidade dos resíduos plásticos. Quimica Nova, v. 29, n. 4, p. 811816, 2006.

GHORMADE, V.; DESHPANDE, M. V.; PAKNIKAR, K. M. Perspectives for nanobiotechnology enabled protection and nutrition of plants. Biotechnology Advances, v. 29, n. 
6, p. 792-803, 2011.

GRILLO, R. et al. Chitosan/tripolyphosphate nanoparticles loaded with paraquat herbicide: An environmentally safer alternative for weed control. Journal of Hazardous Materials, v. 278, p. 163-171, 2014.

GUO, M. et al. Preparation and characterization of enzyme-responsive emamectin benzoate microcapsules based on a copolymer matrix of silica-epichlorohydrin-carboxymethylcellulose. RSC Advances, v. 5, n. 113, p. 93170-93179, 2015.

HE, X.; DENG, H.; HWANG, H. MIN. The current application of nanotechnology in food and agriculture. Journal of Food and Drug Analysis, v. 27, n. 1, p. 1-21, 2019.

HEAP, I. The International Herbicide-Resistant Weed Database. Disponível em: <http://weedscience.org/Home.aspx>. Acesso em: 21 jun. 2020.

HORRIGAN, L.; LAWRENCE, R. S.; WALKER, P. How sustainable agriculture can address the environmental and human health harms of industrial agriculture. Environmental Health Perspectives, v. 110, n. 5, p. 445-456, 2002.

HUANG, S. et al. Nanotechnology in agriculture, livestock, and aquaculture in China. A review. [s.l: s.n.]. v. 35

IRFAN, S. A. et al. A review of mathematical modeling and simulation of controlled-release fertilizers. Journal of Controlled Release, v. 271, n. September 2017, p. 45-54, 2018.

KIM, D. Y. et al. Recent developments in nanotechnology transforming the agricultural sector: a transition replete with opportunities. Journal of the Science of Food and Agriculture, v. 98, n. 3, p. 849-864, 2018.

KOUTROS, S. et al. Non-Hodgkin lymphoma risk and organophosphate and carbamate insecticide use in the north American pooled project. Environment International, v. 127, n. September 2018, p. 199-205, 2019.

KUMAR, S. et al. Development and evaluation of alginate-chitosan nanocapsules for controlled release of acetamiprid. International Journal of Biological Macromolecules, v. 81, p. 631637, 2015.

KUMAR, S. et al. Recent advances and remaining challenges for polymeric nanocomposites in healthcare applications. Progress in Polymer Science, v. 80, p. 1-38, 2018.

KUMAR, S. et al. Nano-based smart pesticide formulations: Emerging opportunities for agriculture. Journal of Controlled Release, v. 294, n. December 2018, p. 131-153, 2019.

KUMAR, S.; KUMAR, D.; DILBAGHI, N. Preparation, characterization, and bio-efficacy evaluation of controlled release carbendazim-loaded polymeric nanoparticles. Environmental Science and Pollution Research, v. 24, n. 1, p. 926-937, 2017.

LECHENET, M. et al. Reducing pesticide use while preserving crop productivity and profitability on arable farms. Nature Plants, v. 3, n. March, p. 1-6, 2017.

LI, Z.-Z. et al. Study of UV-shielding properties of novel porous hollow silica nanoparticle 
carriers for avermectin. Pest management science, v. 63, p. 241-246, 2007.

LIECHTY, W. B. et al. Polymers for Drug Delivery Systems. Annual Review of Chemical and Biomolecular Engineering, v. 1, n. 1, p. 149-173, 2010.

MA, Y. Seed coating with beneficial microorganisms for precision agriculture. Biotechnology Advances, v. 37, n. 7, p. 107423, 2019.

MAGHSOUDI, S.; JALALI, E. Noble UV protective agent for Bacillus thuringiensis based on a combination of graphene oxide and olive oil. Scientific Reports, v. 7, n. 1, p. 7-12, 2017.

MANCHIKANTI, P. Chapter 8 - Bioavailability and environmental safety of nanobiopesticides. In: KOUL, O. B. T.-N.-B. T. AND F. P. (Ed.). . [s.1.] Academic Press, 2019. p. 207-222.

MARUYAMA, C. R. et al. Nanoparticles Based on Chitosan as Carriers for the Combined Herbicides Imazapic and Imazapyr. Scientific Reports, v. 6, n. October 2015, 2016.

MCCLEMENTS, D. J. Nanoparticle and Microparticle-based Delivery Systems: Encapsulation, Protection and Release of Active Compounds. [s.1.] CRC Press, 2017.

MONDAL, P.; BASU, M. Adoption of precision agriculture technologies in India and in some developing countries: Scope, present status and strategies. Progress in Natural Science, v. 19, n. 6, p. 659-666, 2009.

NI, B. et al. Environmentally friendly slow-release nitrogen fertilizer. Journal of Agricultural and Food Chemistry, v. 59, n. 18, p. 10169-10175, 2011.

OLIVEIRA, H. C. et al. Nanoencapsulation enhances the post-emergence herbicidal activity of atrazine against mustard plants. PLoS ONE, v. 10, n. 7, p. 1-12, 2015.

OLIVEIRA, J. L. D. et al. Zein Nanoparticles as Eco-Friendly Carrier Systems for Botanical Repellents Aiming Sustainable Agriculture. Journal of Agricultural and Food Chemistry, v. 66, n. 6, p. 1330-1340, 2018.

OUELLET, M. et al. Hindlimb Deformities (Ectromelia, Ectrodactyly) in free-living anurans from agricultural habitats. Journal of Wildlife Diseases, v. 33, n. 1, p. 95-104, 1 jan. 1997.

PARISI, C.; VIGANI, M.; RODRÍGUEZ-CEREZO, E. Agricultural nanotechnologies: What are the current possibilities? Nano Today, v. 10, n. 2, p. 124-127, 2015.

PASCOLI, M. et al. Neem oil based nanopesticide as an environmentally-friendly formulation for applications in sustainable agriculture: An ecotoxicological perspective. Science of the Total Environment, v. 677, p. 57-67, 2019.

PENG, C. et al. Fate and Transformation of CuO Nanoparticles in the Soil-Rice System during the Life Cycle of Rice Plants. Environmental Science and Technology, v. 51, n. 9, p. 49074917, 2017.

PEPPAS, N. A. et al. Hydrogels in pharmaceutical formulations. European Journal of Pharmaceutics and Biopharmaceutics, v. 50, n. 1, p. 27-46, 2000. 
PIEL, C. et al. Agricultural exposures to carbamate herbicides and fungicides and central nervous system tumour incidence in the cohort AGRICAN. Environment International, v. 130, n. May, 2019.

PIMENTEL, D. Environmental and Economic Costs of the Application of Pesticides Primarily in the United States. In: Integrated Pest Management: Innovation-Development Process. [s.1.] Springer Science, 2009. v. 1p. 89-111.

PUOCI; F. et al. Polymer in agriculture: A review. American Journal of Agricultural and Biological Science, v. 3, n. 1, p. 299-314, 2008.

RANI, R. et al. Evaluation of anti-diabetic activity of glycyrrhizin-loaded nanoparticles in nicotinamide-streptozotocin-induced diabetic rats. European Journal of Pharmaceutical Sciences, v. 106, n. April, p. 220-230, 2017.

ROSER, M.; RITCHIE, H.; ORTIZ-OSPINA, E. World Population Growth. Disponível em: $<$ https://ourworldindata.org/world-population-growth>.

SCHMIDT, J. T. et al. Dieldrin-induced neurotoxicity involves impaired mitochondrial bioenergetics and an endoplasmic reticulum stress response in rat dopaminergic cells. NeuroToxicology, v. 63, p. 1-12, 2017.

SHARMA, A. et al. Global trends in pesticides: A looming threat and viable alternatives. Ecotoxicology and Environmental Safety, v. 201, n. May, p. 110812, 2020.

SHARMA, S. et al. Anti-drift nano-stickers made of graphene oxide for targeted pesticide delivery and crop pest control. Carbon, v. 115, p. 781-790, 2017.

SHYLA, K. K.; NATARAJAN, N.; NAKKEERAN, S. Antifungal activity of zinc oxide, silver and titanium dioxide nanoparticles against Macrophomina phaseolina. Journal of Mycology and Plant Pathology, v. 44, n. 3, p. 268-273, 2014.

SIDHU, A.; BARMOTA, H.; BALA, A. Antifungal evaluation studies of copper sulfide nanoaquaformulations and its impact on seed quality of rice (Oryzae sativa). Applied Nanoscience (Switzerland), v. 7, n. 8, p. 681-689, 2017.

SMITH, K.; EVANS, D. A.; EL-HITI, G. A. Role of modern chemistry in sustainable arable crop protection. Philosophical Transactions of the Royal Society B: Biological Sciences, v. 363, n. 1491, p. 623-637, 2008.

SURIYAPRABHA, R. et al. Application of silica nanoparticles in maize to enhance fungal resistance. IET Nanobiotechnology, v. 8, n. 3, p. 133-137, 2014.

TILMAN, D. et al. Forecasting Agriculturally Driven Global Environmental Change. Science, v. 292, p. 281-292, 2001.

TSUIJI, K. Microencapsulation of pesticides and their improved handling safety. Journal of Microencapsulation, v. 18, n. 2, p. 137-147, 2001.

VILCHEZ-ARUANI, J. et al. Genomic effects of a nanostructured alumina insecticide in human peripheral blood lymphocytes in vitro. Heliyon, v. 6, n. 6, 2020. 
WANG, Y. et al. Synthesis and characterization of emamectin-benzoate slow-release microspheres with different surfactants. Scientific Reports, v. 7, n. 1, p. 1-9, 2017.

YANG, F. L. et al. Structural characterization of nanoparticles loaded with garlic essential oil and their insecticidal activity against Tribolium castaneum (Herbst) (Coleoptera: Tenebrionidae). Journal of Agricultural and Food Chemistry, v. 57, n. 21, p. 10156-10162, 2009.

YE, Z. et al. Photo-responsive shell cross-linked micelles based on carboxymethyl chitosan and their application in controlled release of pesticide. Carbohydrate Polymers, v. 132, p. 520 $528,2015$.

YOUNG, M. et al. Multimodal Generally Recognized as Safe ZnO/Nanocopper Composite: A Novel Antimicrobial Material for the Management of Citrus Phytopathogens. Journal of Agricultural and Food Chemistry, v. 66, n. 26, p. 6604-6608, 2018.

ZHANG, N.; WANG, M.; WANG, N. Precision agriculture - A worldwide overview. Computers and Electronics in Agriculture, v. 36, n. 2-3, p. 113-132, 2002. 